Brit. J. prev. soc. Med. (1974), 28, 246-251

\title{
Effect of medical education on smoking behaviour
}

\author{
ANDREA KNOPF AND JOHN WAKEFIELD \\ Department of Social Research, University Hospital of South Manchester, Christie Hospital and Holt Radium \\ Institute, Manchester M20 9BX
}

\begin{abstract}
SUMmARY
At Manchester University medical students ( $\mathrm{n}=658$ ) had more knowledge than law students $(n=245)$ about the hazards of smoking, were more convinced by the relevant evidence, and assessed the risk to health more highly. However, there was no significant difference in their smoking behaviour. Among medical students $61 \%$ were non-smokers, $10 \%$ ex-smokers, and $29 \%$ smokers, of whom three-fifths smoked regularly. During their training they were more likely to start smoking than to give it up, and more likely to increase their consumption than decrease it. Expansion of smoking occurred especially in the early years of the course, whereas the main increase in knowledge was in the clinical period. Students' knowledge and their opinion of the evidence were related to their stage of education, whereas their assessment of the risk was linked with their smoking behaviour. Expansion of smoking at medical school may be forestalled by providing information about the hazards as early as possible, although some smokers will continue the habit irrespective of knowledge.
\end{abstract}

\section{INTRODUCTION}

Although medical students receive considerable information about the hazards of smoking, some of them do smoke, posing problems for their future roles as health educators and exemplars. Bynner (1967) found a similar incidence of smoking among medical and non-medical students, although the former were more likely to accept the association between smoking and disease. He suggested the first clinical year as the best time for antismoking education. Mausner (1966) noted that although knowledge increased as the course progressed, this was not associated with differences in attitudes or behaviour. In the present study medical students are compared with law students in terms of their smoking behaviour, knowledge, and opinions; progressive changes in these that occur at medical school are then considered.

\section{SAMPLe AND MeThod}

A questionnaire was sent in 1972 to all 726 medical students at Manchester University (response $91 \%$, $\mathrm{n}=658$ ) and to 288 law students (response $85 \%, n=245$ ).

The Manchester medical course lasts for five years, falling into two sections, pre-clinical (years 1 and 2) and clinical (years 3, 4, and 5). The students' mean age was $21 \cdot 5$ years, and about one-third $(n=209)$ were women, the proportion being only one-fifth in the final year. The law course lasts for three years, the students' mean age was 20.4 years, and one quarter were women $(n=61)$.

\section{FINDINGS}

To assess the accuracy of their knowledge, the students were asked to say which of eight diseases were associated with smoking. Six were so associated (Royal College of Physicians, 1971); two were not (colitis and glaucoma). Giving each correct answer a score of 1 (maximum $=8$ ), the medical students' mean score was $5 \cdot 3$, compared with 3.9 for the law students. The two groups were similarly informed about lung cancer, chronic bronchitis, and cancer of the larynx, but medical students were more knowledgeable about coronary heart disease, peptic ulcer, and cancer of the bladder (Table I). Fifty-four per cent of the medical students, but only $29 \%$ of the law students, could name another smoking-related condition. Furthermore, the former found the evidence about smoking more convincing than the latter, and were also more likely to regard smoking as a major risk to health (Table II).

For behaviour, the picture is somewhat different (Table III). Of the medical students, $61 \%$ were non-smokers, $10 \%$ ex-smokers (i.e., had smoked at least one cigarette daily for a month in the past), and $29 \%$ were smokers. Law students did not differ significantly. Among the medical students (but not the law students) the men were more likely to be smokers or ex-smokers than the women $\left(\chi^{2}=17 \cdot 23\right.$; 
TABLE I

COMPARISON OF THE KNOWLEDGE OF MEDICAL STUDENTS AND LAW STUDENTS ABOUT EFFECTS OF SMOKING

\begin{tabular}{|c|c|c|c|c|c|c|c|}
\hline \multirow{2}{*}{\multicolumn{2}{|c|}{ Disease }} & \multicolumn{3}{|c|}{ Medical Students $\left(n=656[+2)^{*}\right.$} & \multicolumn{3}{|c|}{ Law Students $\left(n=244[+1)^{*}\right.$} \\
\hline & & $\begin{array}{l}\text { Associated } \\
\text { with Smoking }\end{array}$ & $\begin{array}{c}\text { Not } \\
\text { associated }\end{array}$ & Don't know & $\begin{array}{l}\text { Associated } \\
\text { with Smoking }\end{array}$ & $\begin{array}{c}\text { Not } \\
\text { associated }\end{array}$ & Don't know \\
\hline $\begin{array}{l}\text { Carcinoma lung ... } \\
\text { Chronic bronchitis } \\
\text { Coronary heart disease } \\
\text { Carcinoma larynx } \\
\text { Peptic ulcer } \\
\text { Carcinoma bladder }\end{array}$ & $\begin{array}{l}\cdots \\
\cdots \\
\cdots \\
\cdots\end{array}$ & $\begin{array}{c}\% \\
99 \cdot 7 \\
98.9 \\
85.5 \\
64 \cdot 2 \\
57.0 \\
28.5\end{array}$ & $\begin{array}{r}\% \\
0.2 \\
0.6 \\
5.3 \\
8.5 \\
19.7 \\
47.9\end{array}$ & $\begin{array}{r}\% \\
0 \cdot 2 \\
0 \cdot 5 \\
9 \cdot 2 \\
27 \cdot 3 \\
23 \cdot 3 \\
23 \cdot 6\end{array}$ & $\begin{array}{r}\% \\
98.4 \\
92 \cdot 2 \\
67 \cdot 6 \\
68 \cdot 4 \\
13.9 \\
5 \cdot 7\end{array}$ & $\begin{array}{r}\% \\
1 \cdot 6 \\
11 \cdot 1 \\
4 \cdot 9 \\
28 \cdot 3 \\
48 \cdot 8\end{array}$ & $\begin{array}{r}\% \\
1 \cdot 6 \\
6 \cdot 2 \\
21 \cdot 3 \\
26 \cdot 6 \\
57 \cdot 8 \\
45 \cdot 5\end{array}$ \\
\hline $\begin{array}{l}\text { Glaucoma } \\
\text { Colitis .. }\end{array}$ & $\ddot{*}$ & $\begin{array}{l}5 \cdot 5 \\
3 \cdot 8\end{array}$ & $\begin{array}{l}42 \cdot 2 \\
51 \cdot 7\end{array}$ & $\begin{array}{l}52 \cdot 3 \\
44 \cdot 5\end{array}$ & $\begin{array}{l}2 \cdot 5 \\
2 \cdot 1\end{array}$ & $\begin{array}{l}20 \cdot 9 \\
20 \cdot 1\end{array}$ & $\begin{array}{l}76 \cdot 6 \\
77 \cdot 9\end{array}$ \\
\hline
\end{tabular}

*In all the tables the figures in parentheses indicate the number who did not answer the question.

TABLE II

COMPARISON OF THE VIEWS OF MEDICAL STUDENTS AND LAW STUDENTS ABOUT SMOKING AND HEALTH



*'Don't know' is combined with 'unconvincing' for the $\chi^{2}$ analysis as it implies doubts about the evidence.

†'Not major risk' includes those who answered 'small risk' (the majority), 'no risk', 'don't know', or were unable to choose between 'small' and 'major', since all these answers imply a view contrary to generally held medical opinion.

TABLE III

COMPARISON OF SMOKING BEHAVIOUR OF MEDICAL STUDENTS AND LAW STUDENTS

\begin{tabular}{|c|c|c|c|c|c|c|c|c|}
\hline \multirow{2}{*}{\multicolumn{3}{|c|}{ Smoking Behaviour }} & \multicolumn{2}{|c|}{ Men } & \multicolumn{2}{|c|}{ Women } & \multicolumn{2}{|c|}{ All } \\
\hline & & & Medicine & Law & Medicine & Law & Medicine & Law \\
\hline $\begin{array}{l}\text { Non-smokers } \\
\text { Ex-smokers } \\
\text { Smokers } \\
\end{array}$ & $\ddot{x}$ & $\begin{array}{l}\cdots \\
\cdots\end{array}$ & $\begin{array}{c}\% \\
55 \cdot 8 \\
11.4 \\
32.7\end{array}$ & $\begin{array}{r}\% \% \\
53 \cdot 8 \\
9 \cdot 2 \\
37 \cdot 0\end{array}$ & $\begin{array}{r}\% \\
72 \cdot 6 \\
5 \cdot 8 \\
21 \cdot 6\end{array}$ & $\begin{array}{r}\% \% \\
63 \cdot 9 \\
6 \cdot 6 \\
29 \cdot 5\end{array}$ & $\begin{array}{c}\% \% \\
61 \cdot 1 \\
9 \cdot 6 \\
29.3\end{array}$ & $\begin{array}{r}0 \% \\
56 \cdot 3 \\
8.6 \\
35 \cdot 1\end{array}$ \\
\hline \multicolumn{3}{|c|}{$\begin{array}{l}\text { Total } \\
\mathbf{n}=\end{array}$} & $\begin{array}{l}99 \cdot 9 \\
446 \\
\text { Not }\end{array}$ & $\begin{array}{l}100 \cdot 0 \\
184 \\
\text { nt }\end{array}$ & $\begin{array}{l}208 \cdot 0 \\
\text { Not }\end{array}$ & $\underset{61}{100 \cdot 0}$ & $\begin{array}{r}100 \cdot 0 \\
655\left(\begin{array}{l}+3) \\
\text { Not }\end{array}\right.\end{array}$ & $\begin{array}{l}100 \cdot 0 \\
245 \\
\text { int }\end{array}$ \\
\hline
\end{tabular}

*Three students did not answer the question about smoking and one did not indicate his/her sex.

$P<0.001)$. Although the law faculty had a smaller proportion of women students this had no effect on the underlying pattern. 1

When age was held constant, only one comparison achieved significance: regular smokers among medical students aged 20 years and below tended to smoke fewer cigarettes than those among law students of the same age. In both groups the younger students had less smoking experience than those aged 21 years and above.
Sixty per cent $(n=116)$ of the medical smokers and $65 \%(n=56)$ of the law smokers smoked regularly (at least one cigarette daily), and a quarter of each group of regular smokers smoked 20 or more cigarettes daily.

The evidence indicates that smoking increases while students are at medical school. This section of the findings is based on recall of past behaviour, 
sometimes from several years previously. Such data are subject to error and it would be unwise to rely on their precision. However, certain basic trends are suggested, and it is with these that we are concerned. Although there was a significant difference $\left(\chi^{2}=22.26, P<0.005\right)$ in smoking incidence at various stages of the course (present behaviour; Table IV), this was not the result of the progress of education, but the effect of the differences of age and sex within the population already noted. However, a comparison of the month before entry to medical school and the present (i.e., the time of the survey) indicates that present behaviour is based on the situation before entry, and that for each intake of students the size of the non-smoker group had declined during their time at medical school (with the exception of the first-year women). Although men and women do not follow exactly the same pattern, the variations do not appear to be systematic, illustrating a general point-that each group of students had its own pattern of behaviour based on the situation before entry, combining with the new environment to produce a unique picture for each intake. In general, women were less likely to have changed their behaviour, whatever it had been originally. The table only illustrates the net adjustment in the size of the groups and disguises the level of exchange between them. For instance, of the 98 final-year students, 18 had become smokers at medical school, although three had subsequently given up, and 12 who began as smokers had also stopped. A net increase of three smokers seems minimal in five years, but the overall level of smoking experience had risen considerably, irrespective of the number currently smoking. Furthermore (Table V) cigarette consumption had also expanded. In each year there were more regular smokers than there had been at entry.

Students also prepared a graph of their smoking behaviour at medical school and these indicated that, among any intake of students at any stage of the course, the number who increased their consumption almost always exceeded the number

TABLE IV

SMOKING BEHAVIOUR OF MEDICAL STUDENTS AT PRESENT AND IN MONTH BEFORE ENTRY INTO MEDICAL SCHOOL

\begin{tabular}{|c|c|c|c|c|c|c|c|}
\hline & & \multicolumn{3}{|c|}{ Month before Medical School } & \multicolumn{3}{|c|}{ Present } \\
\hline \multicolumn{2}{|c|}{ Present Year of Course } & Non-smokers & Ex-smokers & Smokers & Non-smokers & Ex-smokers & Smokers \\
\hline $\begin{array}{ll}\text { Men } \\
1 & n=96 \\
2 & n=99(+1) \\
3 & n=91(+2) \\
4 & n=81 \\
5 & n=78\end{array}$ & $\begin{array}{l}. \\
\cdots \\
\cdots \\
\cdots\end{array}$ & $\begin{array}{c}\% \\
71 \cdot 9 \\
69 \cdot 7 \\
58 \cdot 2 \\
69 \cdot 1 \\
57 \cdot 7\end{array}$ & $\begin{array}{l}\% \\
8 \cdot 3 \\
1 \cdot 0 \\
8 \cdot 8 \\
4 \cdot 9 \\
7 \cdot 7\end{array}$ & $\begin{array}{c}\% \\
19 \cdot 8 \\
29 \cdot 3 \\
33 \cdot 0 \\
25 \cdot 9 \\
34 \cdot 6\end{array}$ & $\begin{array}{c}\% \\
67 \cdot 7 \\
60 \cdot 6 \\
48 \cdot 4 \\
56 \cdot 8 \\
43 \cdot 6\end{array}$ & $\begin{array}{c}\% \\
11 \cdot 5 \\
7.1 \\
11.0 \\
8 \cdot 6 \\
20 \cdot 5\end{array}$ & $\begin{array}{c}\% \\
20 \cdot 8 \\
32 \cdot 3 \\
40 \cdot 7 \\
34 \cdot 6 \\
35 \cdot 9\end{array}$ \\
\hline $\begin{array}{ll}\text { Women } \\
1 & n=55 \\
2 & n=49(+1) \\
3 & n=43 \\
4 & n=41 \\
5 & n=20\end{array}$ & $\begin{array}{l}\ldots \\
\because \\
\cdots \\
\cdots\end{array}$ & $\begin{array}{l}80.0 \\
77.6 \\
81.4 \\
92.7 \\
75.0\end{array}$ & $\begin{array}{l}\frac{1 \cdot 8}{4 \cdot 7} \\
=\end{array}$ & $\begin{array}{r}18 \cdot 2 \\
22 \cdot 5 \\
14 \cdot 0 \\
7 \cdot 3 \\
25 \cdot 0\end{array}$ & $\begin{array}{l}80.0 \\
69.4 \\
67.4 \\
75.6 \\
65.0\end{array}$ & $\begin{array}{r}3 \cdot 6 \\
8 \cdot 2 \\
11 \cdot 6 \\
2 \cdot 4 \\
-\end{array}$ & $\begin{array}{l}16 \cdot 4 \\
22 \cdot 5 \\
20 \cdot 9 \\
22 \cdot 0 \\
35 \cdot 0\end{array}$ \\
\hline $\begin{array}{ll}\text { All } & \\
1 & n=151 \\
2 & n=148(+2) \\
3 & n=134(+2) \\
4 & n=123 \\
5 & n=98\end{array}$ & $\begin{array}{l}\ldots \\
\cdots \\
\cdots\end{array}$ & $\begin{array}{l}74 \cdot 8 \\
72 \cdot 3 \\
65 \cdot 7 \\
76 \cdot 4 \\
61 \cdot 2\end{array}$ & $\begin{array}{l}6 \cdot 0 \\
0 \cdot 7 \\
7 \cdot 5 \\
3 \cdot 3 \\
6 \cdot 1\end{array}$ & $\begin{array}{l}19 \cdot 2 \\
27 \cdot 0 \\
26 \cdot 9 \\
20 \cdot 3 \\
32 \cdot 7\end{array}$ & $\begin{array}{l}72 \cdot 2 \\
63 \cdot 5 \\
54 \cdot 5 \\
62 \cdot 6 \\
48 \cdot 0\end{array}$ & $\begin{array}{r}8 \cdot 6 \\
7 \cdot 4 \\
11 \cdot 2 \\
6 \cdot 5 \\
16 \cdot 3\end{array}$ & $\begin{array}{l}19 \cdot 2 \\
29 \cdot 1 \\
34 \cdot 3 \\
30 \cdot 9 \\
35 \cdot 7\end{array}$ \\
\hline
\end{tabular}

TABLE V

CONSUMPTION OF SMOKERS AT PRESENT AND IN MONTH BEFORE ENTRY INTO MEDICAL SCHOOL

\begin{tabular}{|c|c|c|c|c|c|c|c|c|c|}
\hline & & & & \multicolumn{3}{|c|}{ Month before Medical School } & \multicolumn{3}{|c|}{ Present } \\
\hline & \multicolumn{3}{|c|}{ Present Year } & $\begin{array}{c}\text { Occasional } \\
\text { Smokers }\end{array}$ & $\begin{array}{c}\text { Regular } \\
\text { Smokers }\end{array}$ & Total & $\begin{array}{c}\text { Occasional } \\
\text { Smokers }\end{array}$ & $\begin{array}{l}\text { Regular } \\
\text { Smokers }\end{array}$ & Total \\
\hline $\begin{array}{l}1 \\
2 \\
3 \\
4 \\
5\end{array}$ & $\begin{array}{l}. . \\
\because \\
\because \\
.\end{array}$ & $\begin{array}{l}\because \\
\because \\
\because \\
\ddot{x}\end{array}$ & $\begin{array}{l}\cdots \\
\cdots \\
\cdots \\
\cdots\end{array}$ & $\begin{array}{c}n \\
18 \\
19 \\
14 \\
10 \\
13\end{array}$ & $\begin{array}{l}\text { n } \\
11 \\
21 \\
22 \\
15 \\
19\end{array}$ & $\begin{array}{c}n \\
29 \\
40 \\
36 \\
25 \\
32\end{array}$ & $\begin{array}{r}\mathbf{n} \\
17 \\
17 \\
18 \\
16 \\
8\end{array}$ & $\begin{array}{l}n \\
12 \\
26 \\
29 \\
22 \\
27\end{array}$ & $\begin{array}{l}n \\
29 \\
43 \\
47 \\
38 \\
35\end{array}$ \\
\hline
\end{tabular}


who decreased it, and in general the widest disparities were in the preclinical period, for each intake the smallest number of decreases occurring in the first year. Although the tendency to increase consumption remained, the tendency to decrease grew as the course progressed, although not at the same pace for each set of students. Table VI indicates the year in which students, according to their graphs, became occasional or regular smokers compared with the month before medical school. New smokers tended to take up the habit, and in particular became regular smokers, during the early years of the course. Since increases were recorded at all stages on the graphs, it appears that, once past the first clinical year, these were largely confined to the number of cigarettes consumed by established smokers.

As for the growth of knowledge, the mean accuracy score of the students of individual years improved as the course progressed- $4 \cdot 2,4 \cdot 7,5 \cdot 9$, $5 \cdot 7,6 \cdot 4$, respectively-whereas that of law students did not improve. The main difference lay between preclinical and clinical students: only $2 \%$ of the preclinical students, but $32 \%$ of their clinical colleagues, gave 7 or 8 correct answers, whereas $53 \%$ of the former, as opposed to only $10 \%$ of the latter, scored 4 or fewer points $\left(\chi^{2}=184 \cdot 61\right.$, $P<0.001)$. Under $40 \%$ of preclinical students could name a further condition, compared with $61 \%, 64 \%$, and $85 \%$, respectively, of those in the clinical years. Furthermore, whereas preclinical responses were often minor ailments, clinical students knew of more serious disorders associated with smoking. The tendency to find the evidence 'very' rather than 'fairly' convincing also increased as the course progressed, and no students thought it unconvincing after the first clinical year $\left(\chi^{2}=35.43, \mathrm{P}<0.001\right)$. However, assessment of the risk was not so related; the majority of students in each year $(80 \%, 79 \%, 84 \%, 80 \%, 87 \%$, respectively) thought smoking is a major risk to health.
Superior knowledge did not lead to a lower level of smoking behaviour; indeed, among medical students the smokers had better knowledge scores, because there were more smokers among the clinical students. Nor was smoking behaviour related to the students' opinion of the evidence. Interestingly, however, smoking behaviour was linked to the assessment made of the risk; $85 \%$ of non-smokers and $89 \%$ of ex-smokers considered there is a major risk, compared with only $71 \%$ of the smokers $\left(\chi^{2}=21 \cdot 12, \mathrm{P}<0.001\right)$.

\section{Discussion}

Both strands of the data, the comparison with law students and the examination of progressive changes, lead to the conclusion that a medical education fails to bring about a decline in the incidence of smoking. Not unexpectedly, medical students were better informed than law students about the hazards of smoking, were more convinced by the evidence, and better appreciated the risk involved. Nevertheless, they were just as likely to be smokers, confirming Bynner's (1967) study. True, there was a slightly (but not significantly) lower level of smoking among medical students, but in general students of the humanities are more likely to be smokers than those whose interests are scientific (Peters and Ferris, 1967; Haro and Dilley, 1969). Compared with Bynner (1967), there appears to have been a fall in the levels of smoking among both medical and non-medical students, although these data are based on a much narrower set of observations than Bynner's. A decline has also been noted in the USA (Arnett, Black, and McNeary, 1974). Smoking among medical students may have declined along with that among other students, in the same way as Lynch (1963) suggests that doctors have reduced their smoking along with other professional groups.

Nevertheless, the analysis of change in behaviour indicates that students are more likely both to begin

TABLE VI

NEW SMOKERS* AT MEDICAL SCHOOL

\begin{tabular}{|c|c|c|c|c|c|c|c|c|c|c|c|c|}
\hline & & & \multicolumn{10}{|c|}{ Present Year } \\
\hline \multirow{2}{*}{\multicolumn{3}{|c|}{$\begin{array}{l}\text { Past Year in which } \\
\text { began to smoke }\end{array}$}} & \multicolumn{2}{|c|}{$1(n=151)$} & \multicolumn{2}{|c|}{$2(n=150)$} & \multicolumn{2}{|c|}{$3(n=135)$} & \multicolumn{2}{|c|}{$4(n=123)$} & \multicolumn{2}{|c|}{$5(n=98)$} \\
\hline & & & Occasional & Regular & Occasional & Regular & Occasional & Regular & Occasional & Regular & Occasional & Regular \\
\hline $\begin{array}{ll}1 & \cdots \\
2 & \cdots \\
3 & \cdots \\
4 & \cdots \\
5 & \cdots\end{array}$ & $\begin{array}{l}\ldots \\
\ddot{*} \\
\ddot{*}\end{array}$ & $\begin{array}{l}\ldots \\
\ldots \\
\cdots \\
\cdots\end{array}$ & 1 & 8 & $\begin{array}{l}5 \\
4\end{array}$ & $\begin{array}{l}8 \\
9\end{array}$ & $\begin{array}{l}6 \\
5 \\
1\end{array}$ & $\begin{array}{r}10 \\
3 \\
4\end{array}$ & $\begin{array}{l}3 \\
4 \\
7 \\
2\end{array}$ & $\begin{array}{l}8 \\
4 \\
4 \\
2\end{array}$ & $\begin{array}{l}3 \\
5 \\
4 \\
2\end{array}$ & $\begin{array}{r}8 \\
10 \\
3 \\
2\end{array}$ \\
\hline
\end{tabular}

* One student can appear twice in this table by becoming an occasional smoker and then changing to regular smoking. 
smoking at medical school than to give it up, and to increase their cigarette consumption than to decrease it. Among final-year students, the proportion of non-smokers had fallen from $61 \%$ to $48 \%$ during their training and, although the proportion of ex-smokers grew, so did the proportion of regular smokers.

Prediction is unlikely to be successful, but certain general trends did emerge. The main expansion of the smoking habit occurred during the early years of the course. Increased consumption predominated in the preclinical period, and in particular new smokers took up the habit. Past the first clinical year, increases were largely confined to established smokers, and during the clinical stage decreases tended to counterbalance increases. Neither at Manchester nor Glasgow (Dalton and Curran, 1970) was there any evidence to confirm Bynner's (1967) finding of a reaction in behaviour specific to the first clinical year. Both the accuracy and scope of knowledge about smoking expanded as the course progressed, especially in the clinical years, but this did not lead to a lower level of smoking. Nevertheless, some individuals are influenced to change their habits: decreased consumption was more apparent in the clinical period; and among 92 medical students who were interviewed, eight said the course had influenced them to cut down (Knopf, 1975). Nevertheless, such experience did not prevent others from continuing to smoke, or even taking up the habit. The net effect of increased knowledge is therefore nil. It appears to act as a barrier to even further expansions of the smoking habit but fails to reverse the situation (from a general rather than an individual point of view).

The medical school provides the necessary facts on which to make an informed decision about smoking, but for many it comes too late, during the clinical period, whereas the main expansion of smoking has already occurred at the preclinical stage. An earlier introduction of the topic, preferably in the first year, therefore seems advisable, and this might be done, for example, during anatomy dissection or as project work in social science, i.e., as part of the educative process, not as propaganda.

However, no matter how much information was provided, some smokers would continue the habit, partly because of dependence but also by their ability to persuade themselves that their behaviour is not inconsistent with their knowledge. Both students' knowledge and degree of conviction about the evidence were related to their stage of education, whereas their assessment of the risk was related to their own smoking behaviour, smokers being less likely to think there is a major risk, thus reducing their cognitive dissonance (Festinger, 1957).

Furthermore, the interviews (discussed fully by Knopf (1975)), which examined aspects of the educative process other than simple provision of information, indicated that although most students accepted that not smoking is part of the doctor's exemplar role-smokers, however, were less willing to do so-the idea had not been consistently presented to them. In addition, although some members of staff argued against smoking, most students knew of teachers who smoked, some of whom justified the habit to students. It is likely they have an impact out of all proportion to their numbers, as they stand aside from the conventional medical viewpoint. The ambivalent picture thus presented allows smokers to resist the idea that their personal behaviour has relevance to their future role of doctor. The situation was further confounded by the perception of official policyo in the medical school as one of no more than mildo disapproval.

If it is accepted that, in view of the association between smoking and illness, doctors should beo non-smokers, then clearly medical students need to be discouraged from the habit. Persuading the established smoker to give up is a difficult task, sos greater long-term success may be achieved by more determined effort to prevent further expansion of the smoking habit at medical school. This study has shown that such expansion tends to occur in the early part of the course, whereas the main development of knowledge takes place later, in the clinical stage. Hence, increase may be forestalled if the information is provided as early in the course as possible.

We should like to thank for their advice and cooperation Professor Alwyn Smith, Dr. F. Beswick, Executive Dean, and the administrative staff of the Medical School, and Professor J. T. Farrand, then Dean of the Faculty of Law, all of the University of Manchester. Mrs. J. Clements undertook some of the preliminary work, and Mr. M. Palmer and Mr. D. May advised on some of the statistical procedures.

We are particularly grateful to all the students who took part in the study.

The work was financed by the Department of Health and Social Security.

\section{REFERENCES}

Arnett, J. H., Black, M. W., and McNeary, S. S. (1974). An 11-year study of cigarette smoking habits of students entering Drexel University, Philadelphia. Amer. J. publ. Hlth, 64, 120. 
BYNNER, J. M. (1967). Medical Students' Attitudes towards Smoking. HMSO, London.

Dalton, E. R. and Curran, A. P. (1970). The smoking habits of medical students. Brit. J. prev. soc. Med., $24,61$.

and (Unpublished). Mimeographed version in full. University of Glasgow.

Festinger, L. (1957). A Theory of Cognitive Dissonance. Stanford University Press, Stanford, California.

Haro, M. S. and Dilley, J. M. (1969). The American College Health Association smoking and health project. J. Sch. Hlth, 39, 556.
KNOPF, A. (1975). The medical school and smoking. Brit. J. med Educ., in the press.

LYNCH, G. W. (1963). Smoking habits of medical and non-medical university staff: changes since RCP report. Brit. med. J., 1, 852.

MAUSNER, J. S. (1966). Smoking in medical students. Arch. environm. Hlth, 13, 51.

Peters, J. M. and Ferris, B. G. (1967). Association of smoking with certain descriptive variables in a college age group. J. Amer. coll. Hlth Ass., 16, 165.

Royal College of Physicians (1971). Smoking and Health Now. Pitman Medical and Scientific Publishing Company Limited, London. 